\title{
Pyruvate kinase activity as index of carbohydrate assimilation by mesozooplankton: an early field implementation in the Bay of Biscay,NE Atlantic
}

\author{
Jean-Pierre Bergeron $^{1}$ and Alain Herbland ${ }^{2}$ \\ ${ }^{1}$ : Laboratoire D'ecologie Halieutique, Ifremer, Centre De Nantes,B.P. 21105, F-44311 Nantes \\ 2 : Laboratoire Mixte Cnrs/lfremer Crema, Station De La Rochelle, B.P. 5, F-17137 L'houmeau, France
}

\begin{abstract}
:
Estimates of carbohydrate assimilation within the mesozooplankton compartment are a fundamental concern in oceanography because they give a general expression of the biologically-regulated incorporation of metabolic fuel produced from inorganic nutrients by phytoplankton in the sea. A new tool is proposed for the assessment of such processes. It is based on the measurement of the activity of an enzyme, pyruvate kinase (PK), on samples of the whole mesozooplankton community. Here, the results are presented of an early attempt at such an implementation in the Bay of Biscay (north-east Atlantic) in springtime. A main area situated in front of an estuary (Gironde) has been extensively studied-the same sampling grid was covered on three occasions (two 20 day time lags between each). Strong mesozooplankton PK activities were related to high values of nitrates or chlorophyll a; the inverse was also true. A significant correlation has been found between thermal stratification and enzyme activity. On a brooder scale, in the southern part of the Bay of Biscay continental shelf, the overall significant influence of de-salted water coming from rivers was revealed by spatial variations in mesozooplankton PK activities. The whole dataset suggests that this new tool should be potentially very useful in certain future studies, especially in fisheries oceanography which often requires characterization of mesoscale features.
\end{abstract}




\section{Introduction}

Two decades ago, Mann (1981) stressed that "for understanding biological oceanographic systems, it is necessary to have at least as much information on the fluxes as on the biomasses", an opinion shared by his colleagues of the SCOR Working Group 59 ("Mathematical Models in Biological Oceanography"). The need for such kind of data remains very great nowadays. Especially in pelagic ecosystems, the need for estimates of trophic transfer rates of food particles into the mesozooplankton compartment becomes increasingly crucial, whereas grazing pressure is more and more recognized as playing a major role in primary production regulation (Banse, 1995) : the simple phytoplankton-based feeding is easily assessed by carrying out grazing experiments with incubated copepods or thanks to the gut fluorescence method (Mackas and Bohrer, 1976) ; however, incubation experiments have several drawbacks (Le Borgne, 1986 ; Head, 1988) and it is now widely recognized that strictly herbivorous species are very few and that most of them are rather omnivorous, i.e. essentially microphagous (Kleppel, 1993).

The idea that some natural marine processes could be assessed at the metabolic level was initially introduced by Packard (1969) who proposed to measure the ETS (Electron Transport System) activity to monitor plankton respiration rates. Then original attempts to directly evaluate zooplankton nutrition using digestive enzyme activities measurements were made in the mid-1970 s (Boucher and Samain, 1974 ; 1975 ; Boucher et al., 1976 ; Mayzaud and Conover, 1976). Early works in this field were devoted to a carbohydrase, amylase, as a first step (Boucher and Samain, 1974), rapidly followed by proteasic activities (Boucher and Samain, 1975) and especially trypsin (Boucher et al., 1976). A review by Mayzaud (1986) gives an idea of the number of studies on digestive enzymes in zooplankton during a first decade and, since, this domain remained the object of much work (Mayzaud et al., 1998), 
which permitted considerable advances in the understanding of the biology and ecology of zooplankton, essentially copepods, thanks to laboratory experiments.

However investigations on zooplankton nutrition in the sea come up against the diversity of molecular structures of different classes of carbohydrates which require specific digestive enzymes (Mayzaud, 1986), for their respective assimilation processes. This problem led Mayzaud (1980) and Mayzaud and Mayzaud (1981) to consider necessary the simultaneous study of several carbohydrases, as Hassett and Blades-Eckelbarger (1995) more recently did. Because the bulk of carbohydrate molecules have different polymeric chain structures, their assimilation requires the activities of different digestive enzymes in a first metabolic step. Carbohydrates are the primary metabolic fuel produced in the ocean from inorganic nutrients and consequently they play an essential role in providing energy to phytophagous zooplankters. The importance of this fundamental process in pelagic ecosystems is illustrated by the difference in biochemical composition of phyto- and zooplankton: carbohydrates make up 57\% (refered to dry weight) in phytoplankton whereas zooplankton typically contains less than 5\%, i.e. 1.7\% (Mayzaud and Martin, 1975). Assimilated carbohydrates have two main fates in copepods: they are either directly used as fuel for the metabolism or transformed into lipids to constitute energetic stores (the lipid content is more than $44 \%$ of dry weight in the cited study of Mayzaud and Martin, 1975). Whatever the metabolic orientation, after having followed different pathways (depending on their different macromolecular structures), their catabolism leads to a single 6-carbon- made molecule (fructose 6 phosphate). Afterwards all catabolic steps are strictly the same until the end of glycolysis. If we consider the usefulness of assessing the overall energy yielded by carbohydrate assimilation within the zooplankton compartment, it may be suggested to look at the activity of the common last steps of glycolysis ; the actual last one is catalyzed by pyruvate kinase (PK), which is the terminal enzyme and a key regulator in glycolysis. The PK activity is classically measured with a 
widely-used method (Bucher and Pfleiderer, 1955) and, according to previously stated concepts (Bergeron, 1983; 1986; 1995), the measurements are suggested to be carried out on samples of the whole mesozooplankton community.

An early attempt at such an investigation was made on mesozooplankton collected in the Bay of Biscay during the ERAG ("Ecologie et Recrutement de l'Anchois du golfe de Gascogne") cruise performed in 1994. Optimal assay conditions were first defined in the laboratory and then this field implementation permitted an estimate of both temporal changes in late spring and spatial variations over the southern part of the Bay of Biscay continental shelf. 


\section{Materials and methods}

\section{Field sampling and sample processing}

The ERAG 94 ("Ecologie et Recrutement de l'Anchois du golfe de Gascogne") cruise was carried out from mid May $\left(16^{\text {th }}\right)$ to early June $\left(6^{\text {th }}\right)$ on the R.V. Thalassa. It was preceded, about 20 days before ( $24^{\text {th }}$ to $27^{\text {th }}$ of April), by a shorter cruise, on the coastal R.V. Gwen Drez, during which a sampling grid of 24 stations (10 nautical miles between each) was covered : this AGir ("Anchois Gironde") area was located in front of the Gironde estuary (Figure 1) and was choosen because it is a typical breeding area for the anchovy population in the Bay of Biscay. The AGir area was more comprehensively investigated, with special attention to primary production level (nutrients and chlorophyll a). With the aim of assessing a part of the springtime temporal variation, the Agir sampling grid was covered three times (with two 20 days intervals), the first one with Gwen Drez and both second and third ones at the beginning and the end respectively of the ERAG 94 cruise with Thalassa. Time remaining onboard was devoted to a larger sampling of the southern (from $46^{\circ} 50 \mathrm{~N}$ ) part of the Bay of Biscay continental shelf (Figure 1). 


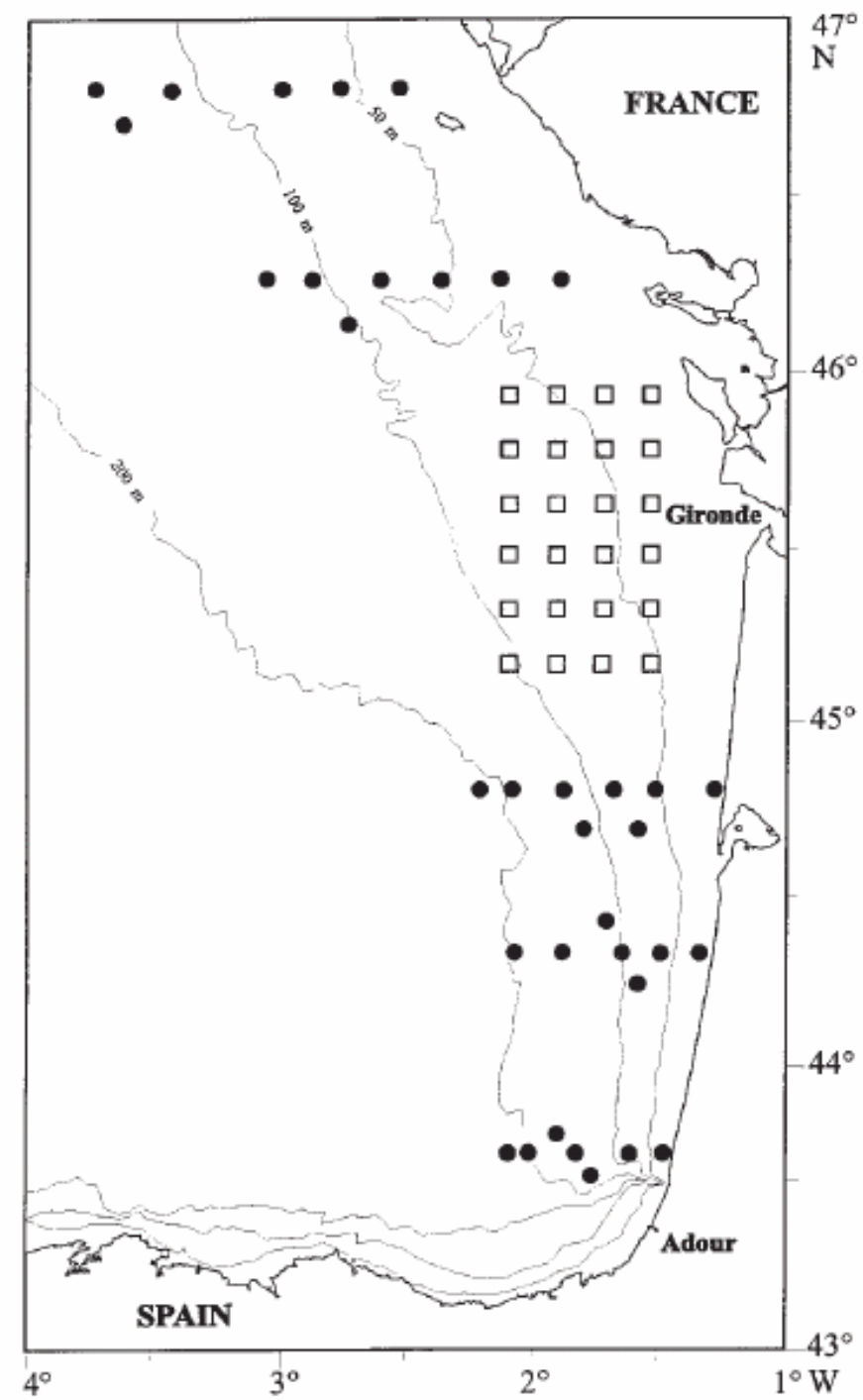

Figure 1. Location of the sampling stations in the southern Bay of Biscay (open squares indicate the AGir area covered on three occasions).

The mesozooplankton samples were collected by vertical tows of WP2 net (200 $\mu$ m mesh size) from the bottom (or from $200 \mathrm{~m}$ depth in the case of the rare oceanic stations) to surface. The macrozooplankton was eliminated by sieving through a $5 \mathrm{~mm}$ mesh. The samples were ground in iced distilled water with a Polytron and immediately frozen at $-40^{\circ} \mathrm{C}$, thereafter stored at $-30^{\circ} \mathrm{C}$ until analysis in the laboratory. After thawing, the crude extract was homogenized again with a Potter-Elvehjem and centrifuged $\left(10 \mathrm{mn}\right.$ at $\left.4000 \mathrm{r} \mathrm{min}{ }^{-1}, 3^{\circ} \mathrm{C}\right)$. An aliquot of $200 \mu \mathrm{l}$ of the supernatant was used for the enzyme assay or protein determination. 


\section{Nutrients and chlorophyll}

Seawater was sampled with 3 or 4 (depending on the water depth) Niskin bottles (8 l). Samples for nutrients $\left(\mathrm{NO}_{3}-\mathrm{N}, \mathrm{NO}_{2}-\mathrm{N}\right)$ were deep frozen and analysed in the laboratory, at the end of each leg, with an autoanalyser (Skalar), according to the standard methods (Strickland and Parsons, 1972). The total chlorophyll $a$ (Chla) was estimated by filtration of $500 \mathrm{ml}$ of seawater on $47 \mathrm{~mm}$ Whatman GFF filters. The filters were deep frozen and analysed at the end of the cruise by the classical acidification fluorometric method (Holm-Hansen et al. 1965).

\section{Enzyme assay}

PK activity was estimated according to the widely-used method of Bucher and Pfleiderer (1955) : the product of enzyme reaction (pyruvate) serves as substrate for a second enzyme, lactate dehydregenase (LDH), added in excess in the mixture ; the functioning of LDH requires the presence of nicotinamide adenine dinucleotide reduced form (NADH) as cofactor, which is oxydized ; its progressive disappearance can be followed by monitoring the decrease of its specific absorbance at $340 \mathrm{~nm}$. Thus PK activity assay is performed using a recording spectrophotometer with water-jacketed cuvette holder for temperature control. Preliminary experiments established optimal $\mathrm{pH}$, substrate and cofactor conditions for zooplankton extracts. Standard assay conditions were defined as follows : $80 \mathrm{mM}$ Tris- $\mathrm{HCl}$ buffer, pH 7.35, 4mM phosphoenolpyruvate (PEP), $67 \mathrm{mM} \mathrm{KCl,} 6.7 \mathrm{mM} \mathrm{Mg} \mathrm{Cl}$, 2mM ADP, $0.15 \mathrm{mM} \mathrm{NADH}$ and $140 \mathrm{U}$ PK-free LDH. Incubation temperature was fixed at $25^{\circ} \mathrm{C}$. Enzyme activity, proportional to the rate of change in absorbance at $340 \mathrm{~nm}$, was expressed as specific activity ( $\mu \mathrm{mol} / \mathrm{min} / \mathrm{mg}$ protein). Protein was estimated by the method of Lowry et al. (1951) with bovine serum albumin as standard. 


\section{Results}

AGir reference area

Results from the AGir area will be considered first because they may be compared with indices of environment fertilization, namely nutrients brought by the river discharge. An unusual increase (from 1 to $4.10^{3} \mathrm{~m}^{3} \cdot \mathrm{s}^{-1}$ in a six days period) of this flow occurred and reached its maximum about ten days before the AGir1 cruise. This explains the relatively high values of nitrate, within the range of $15-25 \mu \mathrm{M}$, and chlorophyll concentrations, up to more than 6 $\mu g . l^{-1}$, measured at some stations close to the mouth of the river (Figure 2A). Both nitrate and Chla distributions show a clear negative gradient from coastal to offshore waters strongly pronunced during AGir 1. Considering the sea surface salinity as an index of outflowing freshwater masses permits to roughly define five clusters of stations which, following a decreasing trend of salinity, present characteristic values of nitrate and chlorophyll a (Table I). It may be noted that the zooplankton PK activity vary accordingly and therefore seems to be strongly influenced by fertilization factors. The spatial variability of PK activity shows up clearly the role played by the river outflow in the marine environment enrichment (Figures $\underline{2 \mathrm{~A}}$ and $\underline{3}$ ) and its effect on the zooplankton metabolism.

Table I. AGir area, first grid (24-27 $7^{\text {th }}$ April) : Definition criteria of five groups of stations according to hydrobiological data and corresponding to different PK activity classes (cf. Figure 3).

\begin{tabular}{cccccc}
\hline $\begin{array}{c}\text { Groups of } \\
\text { stations }\end{array}$ & Surface salinity & $\mathrm{NO}_{3}$ & Chla & $\begin{array}{c}\text { PK } \\
\text { activity }\end{array}$ & $\begin{array}{c}\text { Stations } \\
\text { no. }\end{array}$ \\
\hline 1 & 30 & 15.3 & 6.3 & 463 & 1 \\
2 & $30.5-31.5$ & $16-25$ & $1-2$ & 250 & 3 \\
3 & $32-34$ & $5-7$ & $4-7$ & $150-180$ & 5 \\
4 & $>34$ & $5-7$ & $<0.4$ & $90-170$ & 5 \\
5 & $>34$ & $<4$ & $<1$ & $<80$ & 7 \\
\hline
\end{tabular}




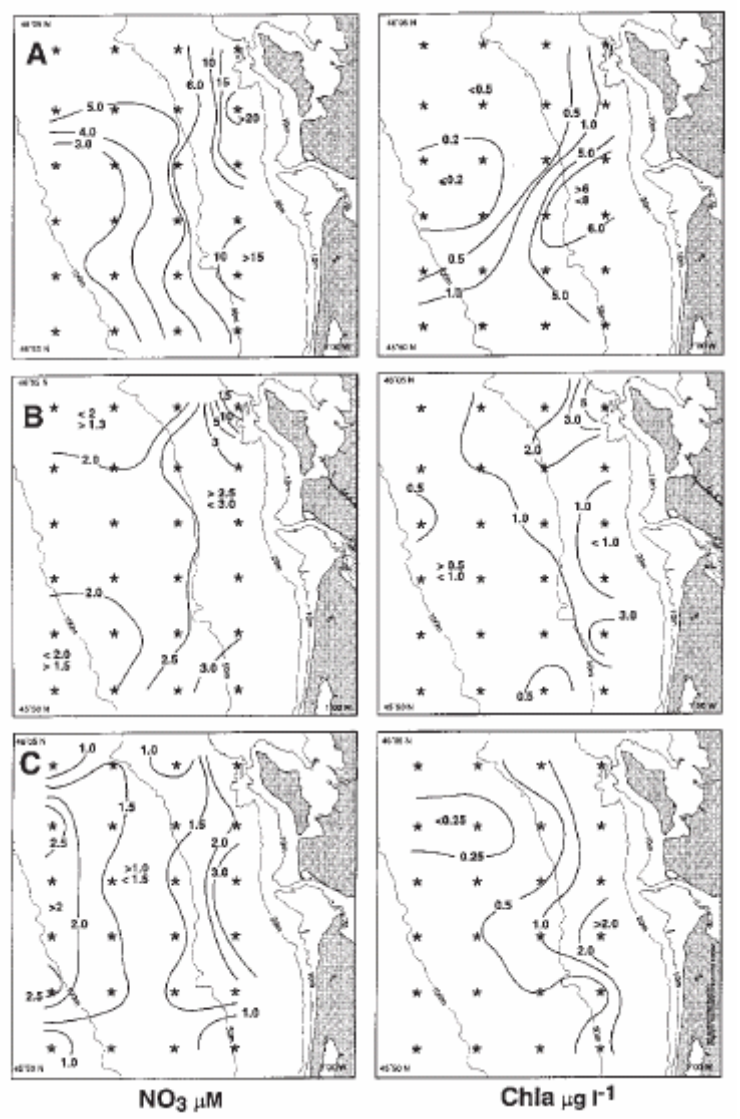

Figure 2. Spatial and temporal variations of NO3 (left side of the figure) and Chla (right side of the figure) during the cruises AGir 1 (A), AGir 2 (B) and AGir 3 (C).

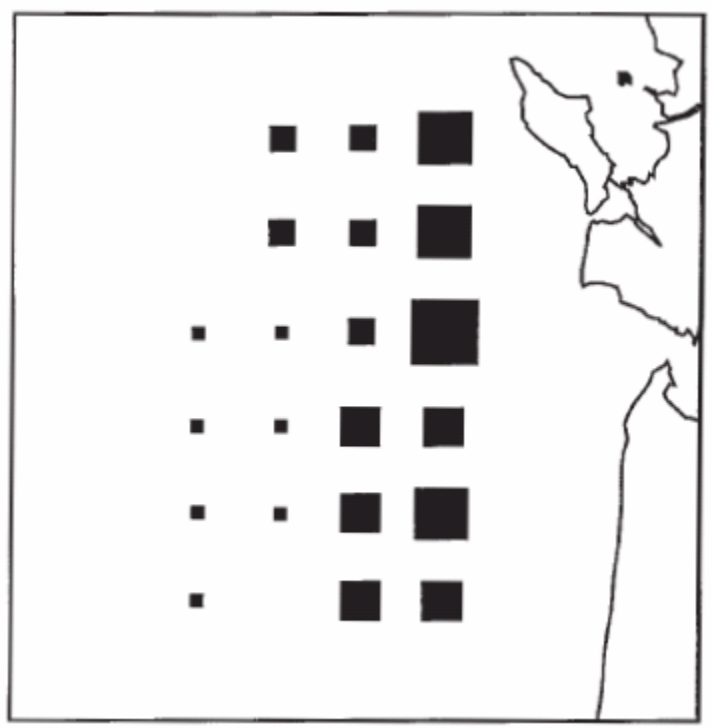

Figure 3. AGir area in front of the Gironde estuary, first grid (April, 24-27 ${ }^{\text {th }}$ ) : variations in mesozooplankton PK activities in connection with hydrobiological data (cf. Table I : the sizes of the squares vary according to the five defined groups, decreasing from the first to the $5^{\text {th }}$ one). 
Thermal stratification, well-known as stimulating marine biological productivity, may be roughly estimated by differences in temperature between near surface (-4 m) and 20 meters depth and presents rather large variations on the whole area : PK activity of mesozooplankton is significantly ( $\mathrm{r}=0.55$; $\mathrm{P}<0.01$ ) correlated with the thermal stratification, the correlation becomes highly significant $(r=0.83)$ by removing the highest PK activity value (cf. Table I) measured at the station located just in front of the mouth of the estuary (Figure 3). This may be interpreted as revealing a non-linear relationship beyond certain thresholds: this highest value is recorded just where both nitrates and chlorophyll a reach together very strong levels. Both second and third samplings of this area show the persistence of the spatial gradients, although much less important than during AGir1, and an obvious decrease of the enrichment factors (Figure 2B-C) accompanied by a decrease of PK activities within the same range (TableII).

Table II.Temporal changes in hydrobiological environment and PK activities between the three samplings of the AGir area grid (number of PK activity measurements in brackets).

\begin{tabular}{|c|c|c|c|c|c|c|c|c|}
\hline & \multirow[t]{2}{*}{ Dates } & \multicolumn{2}{|c|}{$\mathrm{NO}_{3}$} & \multicolumn{2}{|c|}{ Chla } & \multicolumn{2}{|c|}{$\begin{array}{c}\text { PK } \\
\text { activity }\end{array}$} & \multirow[t]{2}{*}{$\begin{array}{c}\text { Stations } \\
\text { no. }\end{array}$} \\
\hline & & Mean & S.D. & Mean & S.D. & Mean & S.D. & \\
\hline AGir 1 & $24-27 / 4$ & 6.9 & 5.8 & 2.0 & 2.5 & 144 & 97 & $24(21)$ \\
\hline AGir 2 & $16-18 / 5$ & 2.8 & 2.9 & 1.0 & 1.2 & 65 & 28 & $24(20)$ \\
\hline AGir 3 & $3-5 / 6$ & 1.8 & 1.0 & 0.7 & 0.6 & 54 & 27 & 24 \\
\hline
\end{tabular}




\section{Southern Bay of Biscay}

Besides the AGir area, a larger sampling grid was covered on the continental shelf (from $43^{\circ} 50$ to $46^{\circ} 50$ North). Water samples were not taken during this part of the cruise, nevertheless mesozooplankton samples were collected and first devoted to an early assessment of the variability of PK activity in the area and for this period of the year cycle. PK specific activity of mesozooplankton varies from 50 up to $340 \mathrm{~m} \mathrm{U}$. mg prot. ${ }^{-1}$, the bulk of these variations being within the range of 100-200. A clear pattern of the enzyme activity shows up first : the highest values are measured at most coastal stations, the lowest seaward and intermediate values on the central part of the continental shelf.

On the whole area, freshwater outflow from the rivers (Adour in the south, Gironde in the north) plays an important role in the marine environment enrichment. Despite the lack of data on nutrients and chlorophyll a, an approach of the overall influence of desalted water may be attempted by studying the spatial pattern of subsurface salinity. Mainly because of the residual circulation (north-northwest general trend), low salinity is generally contained along the coast, where zooplankton PK activities present highest values. This may be generalized and formalized by plotting PK specific activity values against estimates of the magnitude of salinity decrease (expressed by the absolute value of the difference between the salinity recorded at $-4 \mathrm{~m}$ for each station and the maximum found in bottom water, i.e. 35.6). A highly significant correlation is evident $: r=0.61$, with $n=35$. Therefore it seems that changes in PK activity can really reflect mesozooplankton adaptation to potentially different productive conditions. 


\section{Discussion}

The problem of time and space scales is crucial in oceanography. About it, Steele (1978) proposed a famous "very simplified" (according to the author's own words) representation which proved to be both helpful as conceptual guide (well indicated by the number of papers refering to it) and greatly oversimplified regarding the complexity of relationships within the animal community and their fluctuating links with phytoplankton stocks (Banse, 1994). Nevertheless, this outline gives a basis for definition time and space sizes, which should be considered in connection with the general relationship, given by Sheldon et al. (1972), between production rate and particle size applicable to a wide spectrum, i.e. from phytoplankton to fish. Turn over rates of phytoplankton cells may be too high, their life span too short, to allow the assessment of mesoscale processes and "grazing is indeed most important for understanding phytoplankton dynamics" (Banse, 1992). PK activity measurements are suggested to fulfil the concern expressed by Banse (1992) to have a "routine measurement of rates of community ingestion".

Considerable advance in understanding some aspects of the structure and functionning of pelagic ecosystems was made during the past decades, especially during the last one : with the relatively recent emphasis on the role played by different size fractions in zooplankton communities (Morales et al., 1991), a growing number of studies are devoted to the structure of the planktonic food webs (Nielsen et al., 1993 ; Fransz et al., 1998 ; Richardson et al., 1998). In another respect, in a fisheries research perspective (Mann, 1993), the need arises for synthetic characterization of main mesoscale features likely to affect life cycles of fish populations.

The present work was undertaken with the aim of attempting to define a new tool not only for studying feeding in the mesozooplankton compartment, but also, more widely, for characterizing some features of the pelagic food web. Development of biochemical, and 
especially enzymatic, indices has been the object of a large amount of work for more than two decades and it must be recognized that their results sometimes originated debates or were considered as disputable by some authors. Nevertheless the interest in such kind of methods endures because they provide the fastest, simplest and less expensive way to assess mesoscale variations of important metabolic features, as stated by Packard et al. (1996) for ETS activity in estimating the respiration process. Another fundamental advantage of enzymatic methods is the specificity with regard to the targeted metabolic process. It must be emphasized that, unlike other higher (in the trophic interrelationships) animals in the pelagic ecosystem, copepods making up the bulk of mesozooplankton do not store energy in carbohydrate form, i.e. usually as glycogen, but rather as lipids of different molecular structures according to different needs in availability (Sargent and Henderson, 1986). Consequently, PK works only for catabolism of ingested carbohydrates. At last such estimates are supposed to reflect instantaneous metabolic rates which result from a biological integration of the environmental factors having prevailed in the recent life history. An important drawback, according to a number of authors, stems from the only semiquantitative nature of the estimates, especially when they are performed on samples of the whole community (Berges et al., 1993). Even so, it should be underlined that certain precious information about the ecosystem functioning may be gathered thanks to the variability of enzyme activities, especially when variations in space or time show an overall great coherence. It was the case for the early field implementation of PK activities measurements during 94 late spring in the Bay of Biscay. 


\section{Acknowledgements}

We are greatly indebted to several colleagues : P. Bourriau, P. Grellier, D. Halgand and C. Koutsikopoulos for field sampling ; N. Schreiber for biochemical analyses ; C. Dejouy and Y. Descatoire for drawing the figures. Thanks are also due to J. Massé, manager of the IFREMER Project "Ecologie des Petits Pélagiques", and to Captains, officers and crews of the R.V. Gwen-Drez and Thalassa. This study was a contribution to the French "Programme National sur le Déterminisme du Recrutement" (PNDR). 


\section{References}

Banse, K. (1992) Grazing, temporal changes of phytoplankton concentrations, and the microbial loop in the open ocean. In Falkowski, P.G. and Woodhead, A.D. (eds) Primary Productivity and Biogeochemical Cycles in the Sea. Plenum Press, New York, pp. 409-440.

Banse, K. (1994) Grazing and zooplankton production as key controls of phytoplankton production in the open ocean. Oceanogr., 7, 13-20.

Banse, K. (1995) Zooplankton : pivotal role in the control of ocean production. ICES J. Mar. Sci., 52, 265-277.

Bergeron, J.P. (1983) Approche systémique des potentialités de production secondaire pélagique: l'évolution printanière en province néritique. Oceanologica Acta, vol. sp. $\mathrm{n}^{\circ} \mathbf{4}, 15$ 19.

Bergeron, J.P. (1986) Approche systémique des potentialités de production secondaire pélagique: inférences de fluctuations interannuelles. Oceanologica acta, 9, 291-303.

Bergeron, J.P. (1995) Aspartate transcarbamylase activity for the assessment of mesozooplankton production: new aspects from oceanic areas. ICES J. Mar. Sci., 52, 305313.

Berges, J.A., Roff, J.C. and Ballantyne, J.S. (1993) Enzymatic indices of respiration and ammonia excretion : relationships to body size and food levels. J. Plankton Res., 15, 239-254.

Boucher, J. and Samain, J.F. (1974) L'activité amylasique indice de la nutrition du zooplancton : mise en évidence d'un rythme quotidien en zone d'upwelling. Thethys, 6, 179188.

Boucher, J. and Samain, J.F. (1975) Etude de la nutrition du zooplancton en zone d'upwelling par la mesure des activités enzymatiques digestives. In Barnes, H. (ed.) Proc. 9th Europ. Mar. Biol. Symp. Aberdeen University Press, pp. 329-341.

Boucher, J., Laurec, A., Samain, J.F. and Smith, S.L. (1976) Etude de la nutrition, du régime et du rythme alimentaire du zooplancton dans les conditions naturelles par la mesure des activités enzymatiques digestives. In Persoone, G. and Jaspers, E. (eds) Proc. 10th Europ. Mar. Biol. Symp. Universa Press, Wetteren, Belgium, Vol. 2, pp. 85-110.

Bucher, T. and Pfleiderer, G. (1955) Pyruvate kinase from muscle. In Colowick, S.P. and Kaplan, N.O. (eds) Methods in Enzymology. Academic Press, London, Vol. 1, pp. 435-440.

Fransz, H.G., Gonzalez, S.R. and Steeneken, S.F. (1998) Metazoan plankton and the structure of the plankton community in the statified North Sea. Mar. Ecol. Prog. Ser., 175, 191-200.

Hassett, R.P. and Blades-Eckelbarger, P. (1995) Diel changes in gut-cell morphology and digestive activity of the marine copepod Acartia tonsa. Mar. Biol., 124, 59-69. 
Head, E.J.H. (1988). Copepod feeding behavior and the measurement of grazing rates in vivo and in vitro. Hydrobiologia, 167/168, 31-41.

Holm-Hansen, O., Lorenzen, C.J., Holmes, R.W. and Strickland, J.D.H. (1965) Fluorometric determination of chlorophyll. J. Cons. Int. Explor. Mer, 30, 3-15.

Kleppel, G.S. (1993) On the diets of calanoid copepods. Mar. Ecol. Prog. Ser., 99, 183-195.

Le Borgne, R. (1986) The release of soluble end products of metabolism. In Corner, E.D.S. and O'Hara, S.C.M. (eds) The Biological Chemistry of Marine Copepods. Clarendon Press, Oxford, pp. 109-164.

Lowry, O.H., Rosebrough, N.J., Farr, A.L. and Randall, R.J. (1951) Protein measurement with Folin-phenol reagent. J. Biol. Chem., 193, 265-275.

Mackas, D. and Bohrer, R. (1976) Fluorescence analysis of zooplankton gut contents and an investigation of diel feeding patterns. J. Exp. Mar. Biol. Ecol., 25, 77-85.

Mann, K.H. (1981) Guide to the contents. In Platt, T., Mann, K.H. and Ulanowicz R.E. (eds) Mathematical Models in Biological Oceanography. The UNESCO Press, Paris, pp. 11-12.

Mann, K.H. (1993) Physical oceanography, food chains, and fish stocks : a review. ICES J. Mar. Sci., 50, 105-119.

Mayzaud, P. (1980) Some sources of variability in determination of digestive enzyme activity in zooplankton. Can. J. Fish. Aquat. Sci., 37, 1426-1432.

Mayzaud, P. (1986) Digestive enzymes and their relation to nutrition. In Corner, E.D.S. and O'Hara, S.C.M. (eds) The Biological Chemistry of Marine Copepods. Clarendon Press, Oxford, pp. 165-225.

Mayzaud, P. and Conover, R.J. (1976) Influence of potential food supply on the activity of digestive enzymes of neritic zooplankton. In persoone, G. and Jaspers, E. (eds) Proc. 10th Europ. Mar. Biol. Symp. Universa Press, Wetteren, Belgium, Vol. 2, pp. 415-427.

Mayzaud, P. and Martin, J.L.M. (1975) Some aspects of the biochemical and mineral composition of marine plankton. J. Exp. Mar. Biol. Ecol., 17, 297-310.

Mayzaud, P. and Mayzaud, O. (1981) Kinetic properties of digestive carbohydrases and proteases of zooplankton. Can. J. Fish. Aquat. Sci., 38, 535-543.

Mayzaud, P., Tirelli, V., Bernard, J.M., and Roche-Mayzaud, O. (1998) The influence of food quality on the nutritional acclimation of the copepod Acartia clausi. J. Mar. Syst., 15, 483493.

Morales, C.E., Bedo, A., Harris, R.P. and Tranter, P.R.G. (1991) Grazing of copepod assemblages in the north-east Atlantic : the importance of the small size fraction. J. Plankton Res., 13, 455-472. 
Nielsen, T.G., Løkkegaard, B., Richardson, K., Bo Pedersen, F., and Hansen, L. (1993) Structure of plankton communities in the Dogger Bank area (North Sea) during a stratified situation. Mar. Ecol. Prog. Ser., 95, 115-131.

Packard, T.T. (1969) The estimation of the oxygen utilization rate in sea water from the activity of the respiratory electron transport system in plankton. Ph. D. Thesis, University of Washington, Seattle, 115 pp.

Packard, T.T., Berdalet, E., Blasco, D., Roy, S.O., St-Amand, L., Lagacé, B., Lee, K., and Gagné, J.P. (1996). Oxygen consumption in the marine bacterium Pseudomonas nautica predicted from ETS activity and bisulfate enzyme kinetics. J. Plankton Res., 18, 1819-1835.

Richardson, K., Nielsen, T.G., Bo Pedersen, F., Heilmann, J.P., Løkkegaard, B., and Kaas, H. (1998) Spatial heterogeneity in the structure of the planktonic food web in the North Sea. Mar. Ecol. Prog. Ser., 168, 197-211.

Sargent, J.R. and Henderson, R.J. (1986) Lipids. In Corner, E.D.S. and O'Hara, S.C.M. (eds) The Biological Chemistry of Marine Copepods. Clarendon Press, Oxford, pp. 59-108.

Sheldon, R.W., Prakash, A., and Sutcliffe, W.H. Jr. (1972). The size distribution of particles in the ocean. Limnol. Oceanogr., 17, 327-340.

Steele, J.H. (1978) Some comments on plankton patches. In Steele, J.H. (ed.) Spatial Pattern in Plankton Communities. NATO Conference Series, Plenum Press, New York and London, pp. 1-20.

Strickland, J.D.H. and Parsons, T.R. (1972) A practical handbook of seawater analysis. Bull. Fish. Res. Board Can., 167, 1-310. 